\title{
LUKE 22:29-30 AND THE TIME FRAME FOR DINING AND RULING
}

\author{
Peter K. Nelson
}

\section{Summary}

This work addresses the issue of the time frame anticipated by the Lukan Jesus for the fulfilment of the promises in Luke 22:29-30: are the apostles to dine and rule in the church age, in the eschaton, or in both eras? On the basis of verbal, grammatical, contextual, logical, and other factors it is argued that, in spite of the orientation of much recent scholarship, the eschaton, not earlier periods, is in view. Further, neither the differences between Luke 22:29-30 and Matt 19:28 nor the limited thematic likeness between Luke 22:29-30 and apostolic activity in Acts count against this conclusion.

\section{Introduction}

The purpose of the present essay is to consider the time frame, according to Luke, 1 for the events described in Luke 22:29-30:2 'And so, as my Father conferred kingship on me, I confer kingship on you, that you may eat and drink at my table in my kingdom; and you shall sit on thrones ruling the twelve tribes of Israel'.

It is useful to clarify that the Lukan Jesus distinguishes between the time of his conferral of kingship upon the apostles (v. 29) and the time when that conferral is completely fulfilled, its privileges and responsibilities being fully realised. To determine the timing of the initial act, we need only turn to present tense $\delta \imath \tau i \theta \varepsilon \mu \alpha$ in verse 29. It is now, at the Last Supper and during Jesus' speech, that Jesus confers kingship upon the apostles. ${ }^{3}$ That claim may be substantiated with

1 The focus of analysis will be on the Lukan proclamation, not on the historical Jesus or other sub-textual layers of the tradition.

2This issue is addressed in section 7.4.4 (241-48) of my Ph.D. dissertation, 'Leadership and Discipleship: A Study of Luke 22:24-30' (Trinity College, Bristol [CNAA], 1991; this work is forthcoming in the SBL Dissertation Series). The present essay depends upon, yet also develops, the case presented there.

${ }^{3} \delta 1 \alpha \tau i \theta \varepsilon \mu \alpha \mathrm{l}$ here is best understood as an aoristic present because comparative $\kappa \alpha \theta \omega \dot{s}$ likens it to aorist $\delta \dot{\varepsilon} \theta \varepsilon \tau 0$, and because the nature of the act, whether understood as 'to confer', 'to covenant' or 'to will', is 
minimal difficulty, but it does little to specify the time of the conferral's actual realisation.

Subjunctive ě $\sigma \theta \eta \tau \varepsilon$ and $\pi i v \eta \tau \varepsilon$ clearly anticipate a future meal at Jesus' table in his kingdom. Further, it would be senseless for Jesus to confer upon the apostles the right to do at present what they were already doing, namely dining with him. Moreover, $\kappa \alpha \theta \eta \dot{ } \sigma \varepsilon \sigma \theta \varepsilon$ necessarily anticipates a future realisation, and the timing for the present participle кpivov $\tau \varepsilon \varsigma$ is contemporaneous with $\kappa \alpha \theta \dot{\eta} \sigma \varepsilon \sigma \theta \varepsilon$. So the present conferral must await a future fulfilment. 4 What is yet to be determined, however, is how far in the future the conferral's fulfilment is to be. Does Luke 22:30 describe the privileges and responsibilities of the apostles as leaders in the church age, ${ }^{5}$ in the eschaton, ${ }^{6}$ or in both eras? 7

momentary and not continuing or repeated (this counts strongly against the durative or customary present;cf. Acts $9: 34 ; 16: 18)$. The descriptive present is a secondary possibility for $\delta\llcorner\alpha \tau i \theta \varepsilon \mu \alpha \mathrm{l}$. The futuristic present, however, is very improbable since there is no event in the Lukan narrative following 22:30 in which the anticipated action would occur (the giving of 'power' promised in 24:49 and Acts 1:8 looks ahead to the coming of the Holy Spirit-an event experienced by the Jerusalem Christians generally and not only by the apostles-and thus it does not correspond closely to the conferral in Lk. 22:29 which is associated with the ruling position of the Twelve [v 30b]). S. Brown (Apostasy and Perseverance in the Theology of Luke [AnBib 36; Rome, Biblical Institute 1969] 64) makes much of present tense $\delta\llcorner\alpha \tau i \theta \varepsilon \mu \alpha \mathrm{l}$ as favouring a non-eschatological interpretation of 22:2930 (similarly D. Senior, The Passion of Jesus in the Gospel of Luke [Passion Series 3; Wilmington, Glazier 1989] 74; R. Tannehill, 'A Study in the Theology of Luke-Acts', ATR 43 [1961] 201), but he overlooks the important implications of verb moods and tenses in v. 30; v. 29 is made to stand alone as though it had no important links with v. 30 .

${ }^{4}$ So H. Schürmann, Ursprung und Gestalt: Erörterungen und Besinnungen zum Neuen Testament (Düsseldorf, Patmos 1970) 125; idem, Jesu Abschiedsrede Lk 22,21-38 (NTAbh 19/5; Münster, Aschendorff 1957) 41, 46-47, 51; A. George, Études sur l'œuvre de Luc (SB; Paris, Gabalda 1978) 277; against S. Brown, 64, n. 247.

${ }^{5}$ E.g., P. Bossuyt and J. Radermakers, Jésus, Parole de la Grâce selon saint Luc (2nd ed., Vol. 2; Brussels, Institut d'Etudes Théologiques 1984) 476-77; S. Brown, 64; L. Johnson, The Literary Function of Possessions in Luke-Acts (SBLDS 39; Missoula, Scholars 1977) 120; idem, 'The Lukan Kingship Parable', NovT 24 (1982) 152; R. Karris, 'The Gospel According to Luke', 675-721, in The New Jerome Biblical Commentary, ed. R. Brown, et al. (London, Chapman 1989) 716; J. Neyrey, The Passion According to Luke: A Redaction Study of Luke's Soteriology (Theological Inquiries; New York, 


\section{The Thrones Logion in Luke and Matthew}

To address this matter it may be noted first that the time frame in Luke's version of the thrones logion is less explicit than it is

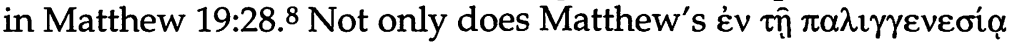

Paulist 1985) 27-28; G. Schneider, Lukas, Theologe der Heilsgeschichte (Bonn, Hanstein 1985) 84; D. Sweetland, 'The Lord's Supper and the Lukan Community', BTB 13 (1983) 25; J. Wanke, Beobachtungen zum Eucharistieverständnis des Lukas, auf Grund der lukanischen Mahlberichte (Erfurter Theologische Schriften 8; Leipzig, St. Benno 1973) 65.

'In the present essay, 'eschaton' and 'eschatological' correspond to the future age of the consummation, the time of the return of the Son of man (cf. Lk. 12:40; 21:27). Arguing for a eschatological focus in 22:29-30 are W. Bösen, Jesusmahl. Eucharistisches Mahl. Endzeitmahl. Ein Beitrag zur Theologie des Lukas (StBib 97; Stuttgart, Katholisches Bibelwerk 1980) 134-39; J. Ernst, Das Evangelium nach Lukas (RNT 3; Regensburg, Pustet 1977) 596; P. Esler, Community and Gospel in Luke-Acts (SNTSMS 57; Cambridge, CUP 1987) 192-3; C. Evans, Saint Luke (TPINTC; London, SCM 1990) 801; J. Fitzmyer, The Gospel According to Luke (AB 28, 28A; Garden City, Doubleday 1981, 1985) 2:1419; George, 277; J. Jervell, Luke and the People of God (Minneapolis, Augsburg 1972) 79; B. Kollmann, Ursprung und Gestalten der frühchristlichen Mahl Feier (GTA 43; Göttingen, Vandenhoeck und Ruprecht 1990) 161, 224; J. Kremer, Lukasevangelium (Wurzburg, Echter 1988) 215; X. Léon-Dufour, 'Le testament de Jésus selon Luc', 266-84, in Le partage du pain eucharistique selon le Nouveau Testament (PD; Paris, Seuil 1982) 276; G. Lohfink, Die Sammlung Israels: Eine Untersuchung zur lukanischen Ekklesiologie (SANT 39; Munich, Kösel 1975) 81-2; D. Lull, 'The Servant-Benefactor as a Model of Greatness (Luke 22:24-30)', NovT 28 (1986) 301-3; Schürmann, Abschiedsrede, 62; C. Talbert, Reading Luke (New York, Crossroad 1984) 210; D. Tiede, Luke (Augsburg Commentary on the NT; Minneapolis, Augsburg 1988) 385; M. Trautmann, Zeichenhafte Handlungen Jesu. Ein Beitrag zur Frage nach dem historischen Jesus (FB 37; Würzburg, Echter 1980) 195; W. Wiefel, Das Evangelium nach Lukas (THKNT 3, 3rd ed.; Berlin, Evangelische 1988) 371-72; et al.

${ }^{7}$ E.g., J.B. Chance, Jerusalem, the Temple, and the New Age in Luke-Acts (Macon, Mercer 1988) 78-79; W. Kurz, Farewell Addresses in the New Testament (Zacchaeus Studies NT; Collegeville, Liturgical 1990) 64-67; A. Loisy, L'Evangile selon Luc (Paris, Nourry 1924) 518; F. Matera, Passion Narratives and Gospel Theologies. Interpreting the Synoptics Through Their Passion Stories (Theological Inquiries; New York, Paulist 1986) 165; D. Senior, 74-76.

8The existence of a sayings document ' $Q$ ' and the independent use of this source by Matthew and Luke is cautiously accepted in the present study. Recent claims for Luke's use of Matthew have been found unconvincing (e.g., M. Goulder, Luke: A New Paradigm (JSNTSup 20; Sheffield, JSOT 1989); cf. my review of this work in Anvil 7 (1990) 256-7). 
('in the restoration, new world') more obviously look to the age

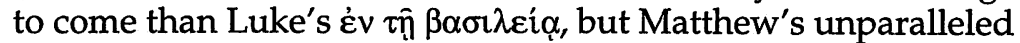
clause 'when the Son of man sits on the throne of his glory' definitely has an eschatological sense ( $c f .25: 31$ ). The timing of the apostles' sitting and judging is then connected to the eschatological enthronement of the Son of man by 'you also' and the repetition of the verb 'sit'.

The lack of these features in Luke 22:29-30 has led some interpreters to suppose that Luke is here signalling a deliberate departure from the eschatological sense of the original logion to shift its focus to the church age. ${ }^{9}$ Since it is most likely that Matthew's reading is more primitive than Luke's (i.e., closer to the $Q$ form), 10 the absence of these eschatological elements in Luke does give us pause. How can this situation be accounted for?

Luke's lack of the above-mentioned eschatological features may be explained as follows. The clause in 19:28 about the enthronement of the Son of man was, in all likelihood, introduced by Matthew to explain the difficult traditional expression év $\tau \hat{n} \pi \alpha \lambda$ เ $\gamma \gamma \varepsilon v \varepsilon \sigma i \alpha, 11$ and thus was not available to Luke. With the words 'you also' Matthew then connects the saying about the Son of man with the thrones logion. The omission of $\dot{\varepsilon} v \tau \hat{\eta} \pi \alpha \lambda \iota \gamma \gamma \varepsilon v \varepsilon \sigma i \alpha$ by Luke (i.e., its replacement with $\dot{\varepsilon} v \tau \hat{n} \beta \alpha \sigma \lambda \lambda \varepsilon i \alpha)$ is probably due to the phrase's difficulty

${ }^{9}$ So e.g., S. Brown, 64; V. Howard, Das Ego Jesu in den synoptischen Evangelien (Marburg, Elwert 1975) 181; S. Schulz, Q: Die Spruchquelle der Evangelisten (Zürich, Theologischer 1972) 331.

10Mt. 19:28 exhibits casus pendens ('a sign of unadorned speech', BDF, § 466; $c f$. J. Theisohn, Der auserwählte Richter. Untersuchungen zum traditionsgeschichtlichen Ort der Menschensohngestalt der Bilderreden des Äthiopischen Henoch [SUNT 12; Göttingen, Vandenhoeck und Ruprecht 1975] 164-5) and other aspects of stylistic inferiority to Lk. 22:29-30 (e.g., 'twelve' is repeated in Mt. 19:28, $\tau \dot{\alpha} \varsigma \delta \omega \delta \delta \varepsilon \kappa \alpha \phi v \lambda \dot{\alpha} \varsigma$ is not separated from

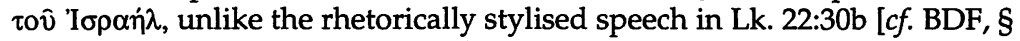
473]); also see F. Beare, The Gospel according to Matthew (Oxford, Blackwell 1981) 400 (the mixing of metaphors in Lk. 22:30 reveals the redactor's hand); J. Dupont, 'Le logion des douze trônes (Mt. 19,28; Lk. 22,28-30)', Bib 45 [1964] 369). See further my dissertation ( $c f$. n. 2 above), sec. 7.2 (187-93), on this topic.

${ }^{11}$ Although Matthew is very interested in the theme of eschatological judgement, the fact that $\pi \alpha \lambda \imath \gamma \gamma \varepsilon v \varepsilon \sigma i \alpha$ appears nowhere else in his Gospel makes it difficult to credit Matthew for this unusual term in 19:28. 
rather than an interest in weakening the saying's eschatological reference.

\section{The Possibility of a Church-Age Fulfilment}

It is true that the apostles in Acts deliver a 'judgement' for the church in Syrian Antioch (15:1-35; note kpív $\omega$ in v. 19), and that Paul then applies this ruling in other cities as well (16:4). But there are three problems with seeing in the Jerusalem. Council a fulfilment of Lk. 22:30b: (1) The decision was not made by the apostles alone, but together with 'the elders' $(15: 6,22) ;(2)$ Strictly speaking, though Peter's testimony in verses 7-11 would have been influential, it was James who delivered the

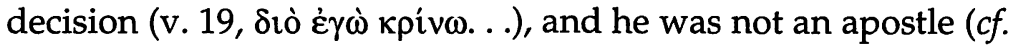
12:2); (3) The decision reached at the Jerusalem Council corresponds to the needs of a largely Gentile congregation, but Luke 22:30 anticipates the rule of the apostles over 'the twelve tribes of Israel'.12

It is acknowledged that Luke describes the apostles as recognised leaders in the Jerusalem church (Acts 4:35), respected teachers (2:42), and as having unusual power for their ministry (2:43). Nevertheless, it is only on this general level that one sees a correspondence between Luke 22:29-30 and the church-age role of the apostles as described in Acts. If Luke had intended 22:29-30 to correlate with the church age, a far stronger correspondence with the content of Acts would have been expected.

J. Neyrey argues, however, that because verses 24-27 and 31-32 have present-age actions of the apostles in view, it is in keeping with the Lukan line of thought to interpret verses 28-30 as having reference to the apostles' church-age leadership. ${ }^{13}$ To be sure, verses 28-29 do describe events which

\footnotetext{
${ }^{12}$ For Luke, the movement spearheaded by Jesus and the apostles, and extended to Gentiles as well as Jews, is conceived of as a single development within Judaism; the church is not external to the 'twelve tribes of Israel', but it shares in the faith of the people of God who have embraced their Messiah. See further my dissertation ( $c f$. n. 2 above), sec. 7.4.3 (238-41); N. Dahl, 'The Story of Abraham in Luke-Acts', 139-58, in L. Keck and J. Martyn (eds.), Studies in Luke-Acts (London, SPCK 1968) 151; J. Fitzmyer, Luke the Theologian (London, Chapman 1989) 194-5; A. George, 'Israël dans l'œuvre de Luc', RB 75 (1968) 523; Jervell, 43.

13Neyrey, 26-27; against $X$. Léon-Dufour, 'Exégèse du Nouveau Testament. Autour des récits de la Passion', RSR 48 (1960) 501.
} 
take place prior to the eschaton, and, if all other things were equal, Neyrey's claim could perhaps shift the balance to a present-era sense for verse 30 . One underestimates Luke's theological concerns and literary skill, however, by ruling out a possible interplay of present and eschatological eras in a text such as the one before us. In fact, the linking of promises for the end-time with instruction for today is important to Luke.14

A more significant objection is that, because the fast of Jesus $(22: 16,18)$ is broken and he eats with the disciples after the resurrection (24:41-43; Acts $1: 4 ; 10: 41)$, he is said to be announcing the arrival of the kingdom as symbolically anticipated in 22:16, 18, 30.15 Two difficulties with this view, however, are as follows: (1) These post-resurrection meals do not have the character of rewards, yet that is what the connection between verses 28 and $29-30$ points to; 16 (2) If Luke saw a fulfilment of verses $29-30$ in these post-Easter meals, we would expect the dining to be paired, in some way, with ruling, but a fulfilment for verse $30 \mathrm{~b}$ is lacking. ${ }^{17}$

A similar objection to the eschatological interpretation of the meal in verse $30 \mathrm{a}$ is that the eucharistic practice of the Christian community as portrayed in Acts (e.g., 2:42, 47; 20:7, 11; 27:35; cf. Lk. 24:30) involves the very table fellowship with Jesus in his kingdom predicted in Luke 22:30a.18 This view, however, fails to reckon adequately with the instruction in 22:19 (

${ }^{14} \mathrm{Cf}$. the joining of $17: 20-37$ and $18: 1-8$; also note the foreshadowing of the eschaton in 12:40 in relation to the call for present-era readiness and faithfulness in 12:35-48.

15Neyrey, 27; Senior, 75.

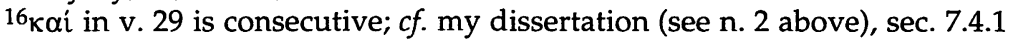
(213).

17The meal in Lk. 24:30 is eucharistic (note the vocabulary of 22:19 and $c f$. J.-M. Guillaume, Luc interprète des anciennes traditions sur la résurrection de Jésus [EBib; Paris, Gabalda 1979] 143) and the eating in 24:41-43 has to do with verifying Jesus' bodily resurrection. Acts 1:4 and 10:41 probably recall the meals of Lk. 24: see I.H. Marshall, The Acts of the Apostles (TNTC; Leicester, IVP 1980) 193.

18Bossuyt and Radermakers, 476; Sweetland, 25; Wanke, 65; cf. Chance, 76. This is to be distinguished from the claim that Luke sees the future meal of 22:30a (and vv. 16, 18) as being the fulfilment or completion of the Eucharist, as Bösen (76-77) and Guillaume (158-59) ably argue.

${ }^{19}$ See Fitzmyer (Luke, 2:1387-88) for a discussion of the text-critical question in 22:19b-20 and a defence of the longer text. 
commands the ongoing observance of the Lord's Supper, but he promises a banquet at his table in his kingdom. Thus we encounter an obstacle of logic: does it make sense for Jesus in verse $30 \mathrm{a}$ to promise a future meal which in verse 19 he commands the apostles to observe? This tension, however, is eliminated if verse $30 \mathrm{a}$ is seen to correspond to the eschatological age.

\section{The Case for Church-Age and Eschaton}

Some maintain that both church and eschatological ages are in view in Luke 22:29-30.20 For instance, J.B. Chance, the scholar who offers the most developed expression of this view, maintains that the opening chapters of Acts present '...the fulfilment, or at least a proleptic fulfilment, of the promise of Luke 22:28-30'.21 The apostles in Acts 5:1-11 exercise their 'eschatological' rule by governing the primitive Christian community, and that community represents Israel. Similarly, the eucharist in Acts emphasises the presence of Jesus and yet anticipates the banquet at the consummation. 22

This kind of solution to the problem before us is attractive in that there is, as noted above, a certain limited thematic likeness between the apostles' actions in Acts and the depiction in Luke 22:29-30-the apostles are leaders in Acts 23 and they observe a meal associated with the presence of Jesusand yet the eschatological element of our text is not overlooked. The question we must ask, however, is whether the actual realization of the conferral of kingship in 22:29-30 is so broad as to encompass apostolic activity in both the church era and the age to come. It is here maintained that it is not.

Chance's linking of the eucharistic practice of the early church with Luke 22:30a encounters the same obstacle of logic noted above, namely that observance of the Lord's Supper is commanded but the banquet of verse $30 \mathrm{a}$ is something promised. Further, though the 'rule' of the apostles in Acts is

${ }^{20} \mathrm{Cf}$. n. 7 above.

${ }^{21}$ Chance, 81. His discussion assumes a definition of 'eschatological' as corresponding to the broad era which the Christ event inaugurates rather than strictly to the end-time (e.g., 78-9, 139-40).

${ }^{22}$ Chance, 72-9.

${ }^{23}$ They were leaders in the pre-Easter period also, according to Lk. 22:26. 
noteworthy, it lacks the aspect of splendour associated with the reward of 'thrones' in 22:30b.

Another weakness of the church-and-eschaton view is that, though Luke does share the concept from the Jesus tradition of the overlapping of ages (the kingdom is 'already but not yet'), to see $22: 29-30$ as being partially fulfilled in the church era would seem to blur the ages and to undermine the newness of the eschatological age. 24

Perhaps the most compelling argument against the church-and-eschaton interpretation is that factors which weigh against the church-age view also tend to count against this possibility. That is, if there are arguments that our text does not look ahead to the church-age (some of these have been given above; others will be noted below), one would naturally expect that the text looks ahead to an era or combination of eras which excludes the church age.

\section{Strengthening the Case for a Reference to the Eschaton}

Having argued that Luke does not aim here to weaken eschatological features in $Q$, and having identified the shortcomings of the church-age and church-and-eschaton understandings of Luke 22:29-30, we may now strengthen the case for the eschatological view.

Various findings concerning Luke's patterns of word usage favour an eschatological understanding. Regarding Lukan occurrences of 'throne' ( $3 x$ in Lk., $2 x$ in Acts), one notes that in no case (setting Lk. 22:30 aside) is a governing or judging role of the apostles over Israel or the church in view, yet the term does tend to have a rather lofty, transcendent character (Lk. 1:32; Acts 2:30; 7:49). ${ }^{25} \beta \alpha \sigma i \lambda \varepsilon i \alpha$ in Luke often corresponds to a future rule or realm in the age to come (e.g., $1: 33 ; 13: 28,29 ; 21: 31 ; 22: 16,18)$, and when the term has the post-

${ }^{24}$ R. Geiger (Die lukanischen Endzeitreden [Europäische Hochschulschriften 23/16; Bern, Lang 1973] 255-6) observes that Luke's conception of the endtime as set out in Lk. 21 involves a wholly new order. By contrast, Chance maintains, 'In short, with the arrival of Jesus, the New Age in its fullest eschatological sense, had dawned' (140).

25Further, the throne image is common in apocalyptic texts (e.g., Dan. 7:910; Mt. 25:31; Rev. 3:21, 20:4-5; T. Job 33). 
Easter period in view 26 it is almost always eschatological. 'Table' language ( $c f .22: 30 \mathrm{a}$ ) is not prominent in Acts, and the typical Gospel formula 'eat and drink' (14x in Lk., only $3 x$ in Acts) is largely replaced in Acts by the eucharistic formula 'breaking of bread' (e.g., 2:42, 46; 20:7, 11; 27:35).

Lukan texts with a feasting image often have eschatological overtones. 27 This is especially apparent in 12:37, 40 , where the return of the serving master symbolises the Parousia of the Son of man. Luke's motif of an eschatological feast $(c f .6: 21 ; 12: 37 ; 13: 29 ; 14: 15 ; 22: 16,18)$ may reflect a tradition from Judaism which regarded banqueting as symbolic of everlasting bliss. ${ }^{28}$ Luke 22:30a thus fits in with a line of Lukan and Jewish thought which anticipated a future banquet in the kingdom, in the age to come.

Going beyond 12:37, 40, correspondences between 12:42-44 and 22:28-30 are also significant for the question at hand. Both texts involve the conferring by the master/king on faithful subordinate leaders of greater ruling authority. What is important here is that in 12:44 this authority is for the period following the return of the master, who clearly symbolises the Son of man (v. 40; $c f .22: 30 b)$.

An additional problem with present-age understandings of 22:29-30 is that they do not account for the pronounced shift of mood in Jesus' discourse beginning at verse 31. With the prediction of Peter's denial (vv. 31-34) and the forecast of an era of opposition (vv. 35-36), Jesus markedly alters the tone of his speech from the hope of celebration and victory to the expectation of adversity and conflict. ${ }^{29}$ Together

${ }^{26}$ Of ten such occurrences in Luke, the church era is in view only once (9:27), and there Luke follows Mark.

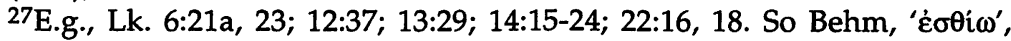
TDNT 2:695; Esler, 192-3; Fitzmyer, Luke, 2:1026, 1419; Guillaume, 146-9; A. Polag, Die Christologie der Logienquelle (Neukirchen-Vluyn, Neukirchener 1977) 49, 52 .

${ }^{28}$ See Str-B 4:1154ff; $c f$. also Isa. 25:6-8; 55:1-2; 65:13-14; 1 Enoch 62:14; 2 Apoc. Bar. 29:4; Pirqe 'Abot 3.20 (cited in Fitzmyer, Luke, 2:1026); cf. Rev. 19:9. Also see my dissertation ( $c f$. n. 2 above), sec. 3.3 (Jewish banquet and meal traditions) and 3.5 (Lukan table motifs).

${ }^{29} \mathrm{~A}$. Schlatter, Die Evangelien nach Markus und Lukas (Erläuterungen zum NT 2; Stuttgart, Calwer 1987) 381. Note the role of $\dot{\alpha} \lambda \lambda \dot{\alpha}$ vv̂v (v. 36) in drawing a sharp contrast between the disciples' earlier mission (10:4) with its positive results $(10: 17-19)$, and the new, different period which is to 
with Acts 14:22 and Luke 9:23, 22:36 prompts the Lukan reader to suppose that the church age would involve significant struggle, and accordingly that 22:29-30 looks ahead to a decisively new era, i.e., the eschaton.

A church-age understanding of 22:29-30 would also run against the grain of Jesus' teaching in verses $25-27$. The elevated honour and authority associated with the future experience of the Twelve in dining at Jesus' table in his kingdom and sitting on thrones to rule Israel is an appropriate expectation only concerning the age to come, for in the present era the Lukan Jesus urges lowly servant leadership. It is leading and 'ruling' the people of God in a way that markedly contrasts with the kings and benefactors of the day (v. 25) and that fully aligns with the striking self-reference of Jesus as 'the one who serves' (v. 27) to which Jesus calls the apostles for their work in the present time.

The similarities of the Lukan and Pauline Institution Narratives may be important here as well. Following his counterpart to Luke 22:20 (1 Cor. 11:25), Paul adds that observance of the Lord's Supper proclaims the Lord's death until he comes (11:26). For Paul, eucharistic experience was clearly associated with eschatological expectation. Further, since Luke has no direct parallel to 1 Corinthians 11:26 but shows strong affinities to the Pauline Institution Narrative, Jesus' prediction in Luke (and the Synoptics) of a future meal/drink in the kingdom of God (Lk. 22:16, 18) coupled with Luke's inclusion of 22:30a may reflect the influence of Paul's eschatological expectation associated with the Last Supper (via his letters or the practice in Pauline churches). ${ }^{30}$

follow in Jesus' absence. The contrast, however, must not be overstated; Peter will be able to turn and strengthen his brothers (22:32), and Acts reveals many mission successes amidst ongoing adversity.

30Jervell supports the eschatological view when he maintains that the seemingly unusual phenomenon of replacing Judas (Acts 1:15-26) but not James (12:2) is due to the eschatological function of the apostles: 'If a new apostle were elected, the eschatological Israel would have thirteen regents over the twelve tribes' $(82 ; c f$. Kurz, 66). While agreeing that for Luke the eschatological role of the apostles is a primary one, it is necessary to note that they also have a present-era transitional function by which they bridge from the life of Jesus to the period of the church. Accordingly, the failure to replace James may signal the beginning of the end of the apostolic transition era rather than imply an eschatological function for 


\section{Conclusion}

The accumulated weight of the above lines of evidence counts in favour of an eschatological realisation of the conferral of kingship in Luke 22:29-30. A comparison with Matthew 19:28 does not suggest that Luke has redacted the logion so as to weaken its eschatological reference. Arguments for a churchage focus in Luke 22:29-30, or for a reference to the apostles' roles in both church and eschaton, encounter various obstacles such as Lukan verbal and thematic preferences, the logic and tone of 22:29-30 in its Lukan context, and insufficient information about the apostles in Acts with which Luke 22:2930 could be aligned. While the initial act of conferral takes place at the moment of Jesus' speech, the fulfilment of that conferral is to be realised only in the eschaton. That is when the apostles will receive their reward of table fellowship with Jesus and be enthroned to govern the twelve tribes of Israel.

In terms of the larger issues of Lukan thought and theology, the present essay weighs against a strongly 'realised' eschatology in which the experience of the church is seen to correspond closely with the life of the people of God in the age to come. Rather, Luke's ecclesiology envisions an ongoing struggle for the church-advance and set-back-in which God's will is progressively accomplished despite human trials and tribulations (Lk. 9:23; 22:36; Acts 14:22). Further, Luke's eschatology looks ahead to a decidedly new and bright future for the community of Jesus Messiah, and accordingly one may infer that Luke would have his readers draw strength and hope for life in the present from the anticipation of the grand rewards to come.

the Twelve (i.e., at some point it had to become necessary not to replace a deceased apostle). 